\title{
Road Network Connectivity Quality Assesment for Timor Leste National Road Network
}

\author{
Frans de Jesus Babo ${ }^{1, \text { a) }}$ \& Hitapriya Suprayitno ${ }^{2, \text { b) }}$ \\ ${ }^{1)}$ Civil Engineering Dept., Universidade da Paz, Dili, Timor Leste. \\ ${ }^{2)}$ Civil Engineering Dept., Institut Teknologi Sepuluh Nopember (ITS), Surabaya, Indonesia. \\ Correspondance : ${ }^{a}$ franslaybabo@gmail.com \& ${ }^{b}$ suprayitno.hita@gmail.com
}

\begin{abstract}
Timor Leste is a very young country. Road network is still pretty the only blood vessel of the economy. Road network need to be well managed following the principle of Infrastructure Asset Management. Thus, the national road network still has to be evaluated against the primary network quality: the connectivity. Assessment indicated that all national center activities are connected by national road network. But, the connectivity cannot be said to be good enough for certains. Due to the mountainous and hilly area, the roads still need to be improved in term of road cross section and road geometry.
\end{abstract}

Keywords : infrastructure asset management, road nework, connectivity quality.

\section{INTRODUCTION}

Timor Leste, officially is named Democratic Republic of Timor-Leste, is very young country. Timor Leste became a sovereign state in 20 May 2002, after Indonesian occupation. As a new state, after long Portugese colonisation, the economic condition is not yet well developed. Economic development depend a lot on the road network quality, as a means for coonecctivity and accessibility (WBG 2018). The connetivity quality of Timor Leste road nework need to be accessed.

According to the Infrastructure Asset Management (IAM), the road network must be well managed, developed, maintained, operated, in accordance to its function, therefore need to evaluated regularly (Suprayitno \& Soemitro 2018; Suprayitno \& Soemitro 2019). The serious study indicated that the road network asset management needs to be developed in Timor Leste (ADB 2015; GHD 2015).

As the Road Network is basic needs for a region or a country, the road network must be always in good quality. It has been formulated that the road network has three main functions : to connect, to access, and to cover (Suprayitno 2014). The road network quality should be assessed regularly. Connectivity is the primary quality of the road network.

This paper present the research result to assess the connectivity quality of the Timor Leste road network.

\section{RESEARCH METHOD}

The research was conducted by following these steps : backgound understanding, research objective designation, research method development, literature review execution, concept development, conclusions drawn. The road network system model is developed based on the national activity center and national road network. The Connectivity Quality is measured based on eye view of the network system model. 


\section{LITERATURE REVIEW}

Two theoritic Literature Reviews are needed for this research, i.e. the IAM Basic Principle, the Road Network Quality Principle.

\section{IAM Basic Principle}

IAM by definition is a knowledge, science, program or action to manage infrastructure through its entire life, to be able to always function well, economically, efficiently effectively and always conform to the sustainability principle. All pertinent risks has been considered (Suprayitno \& Soemitro 2018; Suprayitno \& Soemitro 2019).

\section{Road Network Quality Principle}

Road Network Quality is measure based on its Performance to Execute its Function. The Road Network main function can be defined as three main functions : to connect different nodes, to flow the traffic, and to cover the region. Those main functions can be derived into two sub functions each (Suprayitno 2010; Suprayitno 2014; Suprayitno 2015; Suprayitno 2016; Suprayitno 2018; Suprayitno \& Soemitro 2019). The road network functions are presented in the following Table 1.

Table 1. Road Network Main Function

\begin{tabular}{lll}
\hline Group & As pect & Explanation \\
\hline \multirow{2}{*}{ Connectivity } & $\begin{array}{l}\text { Connectivity } \\
\text { Accessibility }\end{array}$ & $\begin{array}{l}\text { how many that must be connected } \\
\text { the access or egress distance from and to other nodes }\end{array}$ \\
\hline \multirow{2}{*}{ Flow } & $\begin{array}{l}\text { Itinerary } \\
\text { Fluidity }\end{array}$ & $\begin{array}{l}\text { the itinerary distance compared to the direct distance } \\
\text { traffic flow fluidity }\end{array}$ \\
\hline \multirow{2}{*}{ Coverage } & $\begin{array}{l}\text { Coverage } \\
\text { Density }\end{array}$ & $\begin{array}{l}\text { how large is the coverage compare to that must be covered } \\
\text { how many km per area and many km per population }\end{array}$ \\
\hline
\end{tabular}

\section{Connectivity Quality}

Connectivity Quality is wether all nodes that must be connected are connected and how well it is connected. For Timor Leste, the National Road Network must connect all districts, main airport and main ports.

Analyse was done by take the general overview of Timor Leste to identify the important nodes to be connected, to the general overview of the Road Network to identify the National Road Network, and to asses the connectivity quality based on Road Network System Model.

\section{Overview of Timor Leste}

\section{General Overview}

Timor Leste a very young country. She got its souveraignity in 1999. Timor Leste is located on the east tip of Timor island, the western part is Indonesian teritory. With Dili as the capital, the whole country is devided administratively into 13 districts. With a population of $1,167,242$ (2015 sensus) and an area of 15,420 sq.km, its popualtion density is very low at 78 pax/sq.km. The economic condition is still under developed, with the 2017 GNP of US\$ 4567 milyar, the GNP/capita is at US\$ 5479, the Human Development Index is on the rank of 158 . Agriculture is its major economic activity, the industry does not exist yet. 


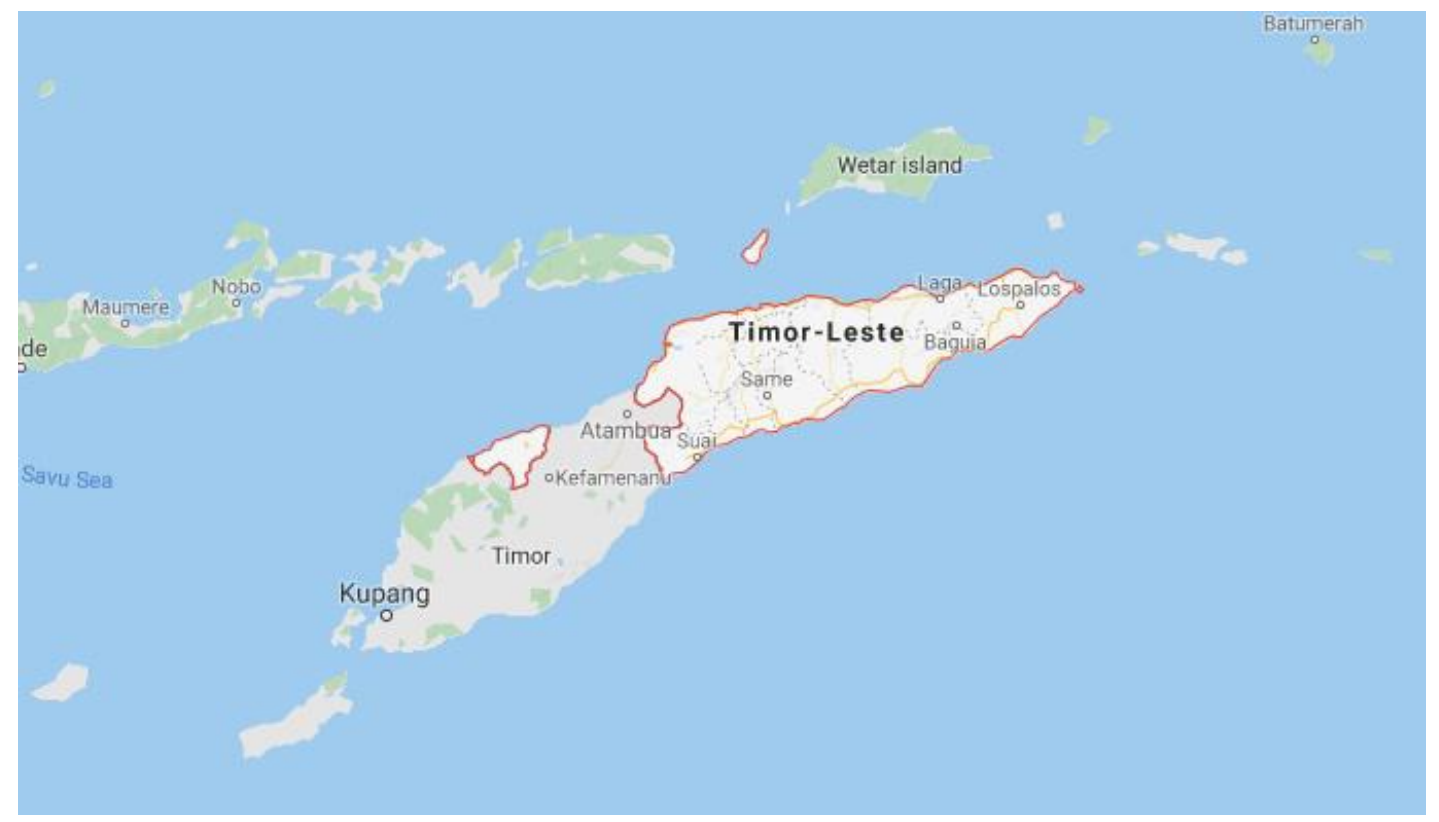

Figure 1. Timor Leste

\section{Natural Geography}

Since Timor Leste is located on the eastern part of Timor island, the area is stretched in east-west direction. Geologically the area is dominated by calcaire formation, so it is very rocky hilly area, and tend to be dry. The hilly and mountaineous area form a backbone stretching also east to west, with the highest points can reach around $2000 \mathrm{~m}$ elevation. Two small islands can be found in the surrounding : atauro and Jaco. The river are small and tend to be dry during dry season, and become torrential during rainy season. A volcanic area can be found in the eastern part of Timor. The climate is tropical, with dry season is between May - November and rainy season is between December - April. Geographical Condition map is presented in Figure 1 below.

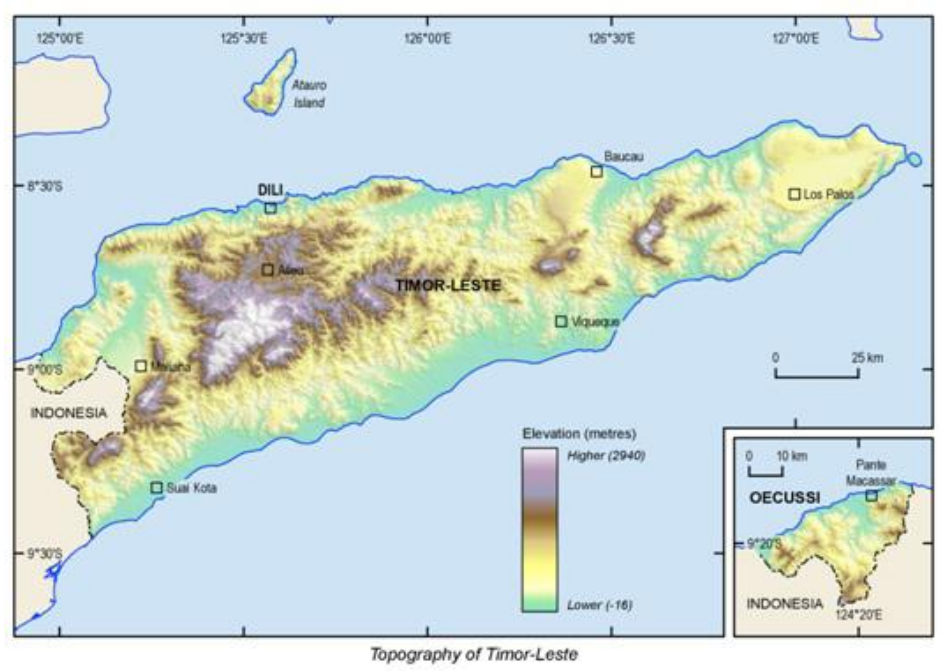

Figure 2. Topograhic Condition of Timor Leste 


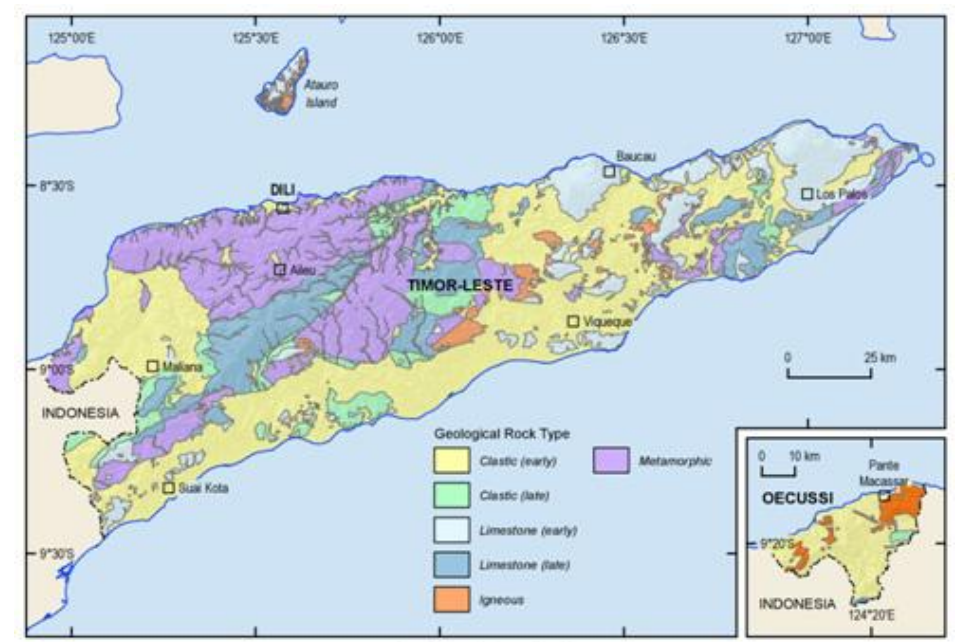

Figure 3. Geologic Condition of Timor Leste

\section{$\underline{\text { Administration }}$}

Timor Leste has Dili city as the capital, located in the north coast. The whole country, of 15,420 sq.km large, is devided into 13 Districts, and each district is organized into several subdistricts. One district, Oecussi-Ambeno is located faraway in the west, separated by Indonesian territory. The main small island north of Dili, Atauro island, administratively is included as Dili city territory.

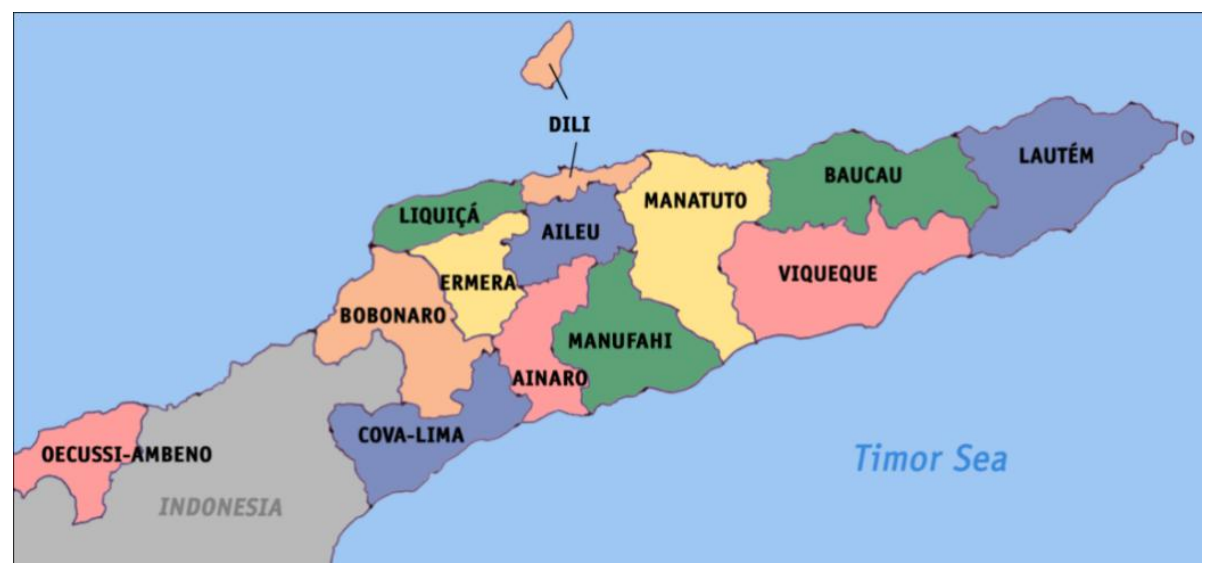

Figure 4. Administrative Region Map

\section{$\underline{\text { Population }}$}

Population of Timor Leste is still small. According to the Timor Leste 2015 Sensus, recorded population is only $1,167,242$ persons. With an area of 15,420 sq.km, the overal density is merely 78 person/sq.km. In term of districts, Dili city is the most dense with a density of 637 person/sq.km, and Manatuto district is the least dense with a density of 24 person $/ \mathrm{km} 2$. Manatuto district is located in south-easth of Dili city. The overall population data is presented in Table 2 below. 


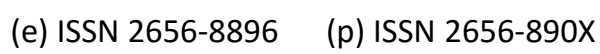

Journal of Infrastructure and Facility Asset Management - Vol. 1. Issue. 2, September 2019

Table 2. Administrative Division and Population Data

\begin{tabular}{rllrrr}
\hline No & District & Capital & $\begin{array}{r}\text { Area } \\
k m 2\end{array}$ & $\begin{array}{r}\text { Population } \\
\text { person }\end{array}$ & $\begin{array}{r}\text { Density } \\
\text { person } k m 2\end{array}$ \\
\hline 1 & Lautem & Lospalos & 1,813 & 59,787 & 32.977 \\
2 & Baucau & Baucau & 1,506 & 111,694 & 74.166 \\
3 & Viqueque & Viqueque & 1,877 & 70,036 & 37.313 \\
4 & Manatuto & Manatuto & 1,782 & 42,742 & 23.985 \\
5 & Dili & Dili & 367 & 234,026 & 637.673 \\
6 & Aileu & Aileu & 737 & 44,325 & 60.142 \\
7 & Manufahi & Same & 1,323 & 48,628 & 36.756 \\
8 & Liquica & Liquica & 549 & 63,403 & 115.488 \\
9 & Ermera & Gleno & 768 & 117,064 & 152.427 \\
10 & Ainaro & Ainaro & 804 & 59,175 & 73.601 \\
11 & Bobonaro & Maliana & 1,376 & 92,049 & 66.896 \\
12 & Cova-Lima & Suai & 1,203 & 59,455 & 49.422 \\
13 & Oecussi-Ambeno & Pante Macassar & 814 & 64,025 & 78.655 \\
\hline \multicolumn{7}{r}{} & & 14,919 & $1,066,409$ & 71.480 \\
\hline
\end{tabular}

\section{Economics}

Produced by the World Bank Group, several Economic Key Indicators for the year of 2017 are, the Population is 1.3 million, Current Gross Domestic Product (GDP) is US\$ 1.7 billion, it produce GDP paer capita of US\$ 1,299. Basic needs proverty rate is $30.3 \%$, Primary School enrollment was $96.8 \%$. Life expectancy is 68 years at birth. The main export commodity were coffee and petrol, but the two were getting down in 2017, while the import growed up in 2017. The government spending is 70\% of the GDP. The main economic activity is mainly still agriculture, but rough terrains give difficulties for the rice field agriculture (WBG 2018).

\section{Transportation}

Timor Leste is very small country. So domestic transport is serve only by road transport. Even the capital, with a population of around 300.000, does not need other then road transport (GHD 2015). The main road network is presented in Figure 4 below.

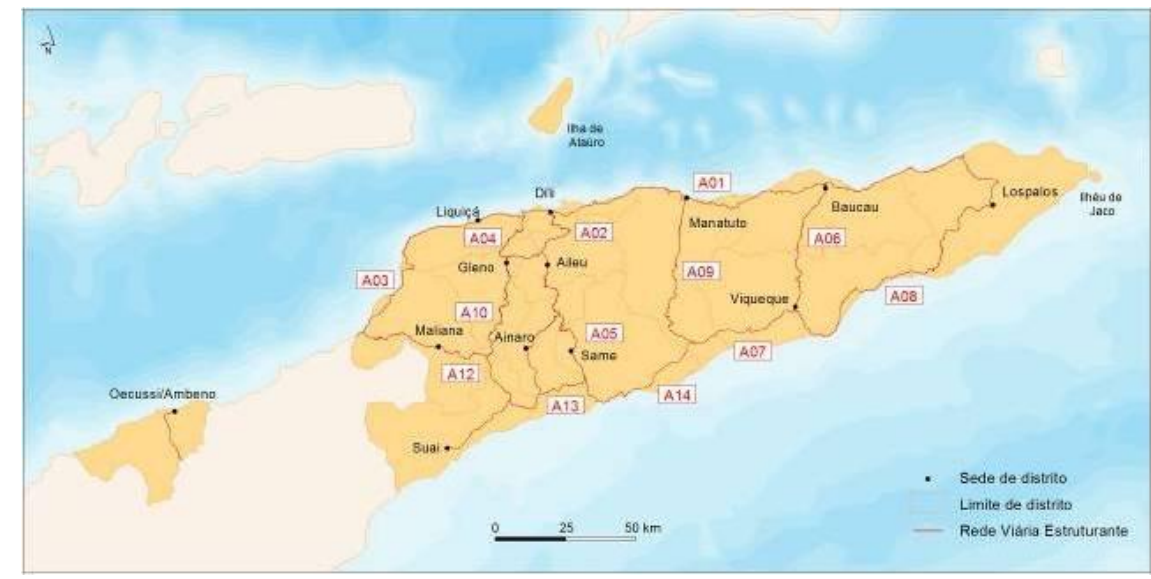

Figure 5. Timor Leste National Road Network

Meanwhile, international connection for passenger is serve by air transportation and for freight by sea transportation. The main airport, the international airport Presidente Nicolao Lobato is located at Dili; while the second new airport, the domestic airport Rota do Sandalo 
is located in Oecasse.. The main port, the international sea port Porto Dili is also located in Dili. This sea port receive containers from international freight. But the road network and the trucking system is not yet capable of transporting the container to the destination, so bongkarmuat from the container are done in the container yard outside the Porto Dili area operated by ANL (GHD 2015).

Road vehicle types circulated in Tinmor Leste can be classified as follows. Vehicle types for passenger transportation are : motorcycle, tricycle, sedan, SUV, micro bus, medium bus, and standard bus. While vehicle type for freight are pick-up, light truck, mideum truck, and heavy truck. The semi trailer are operated only to transport the containers from Porto Dili to the ANSL container yard.

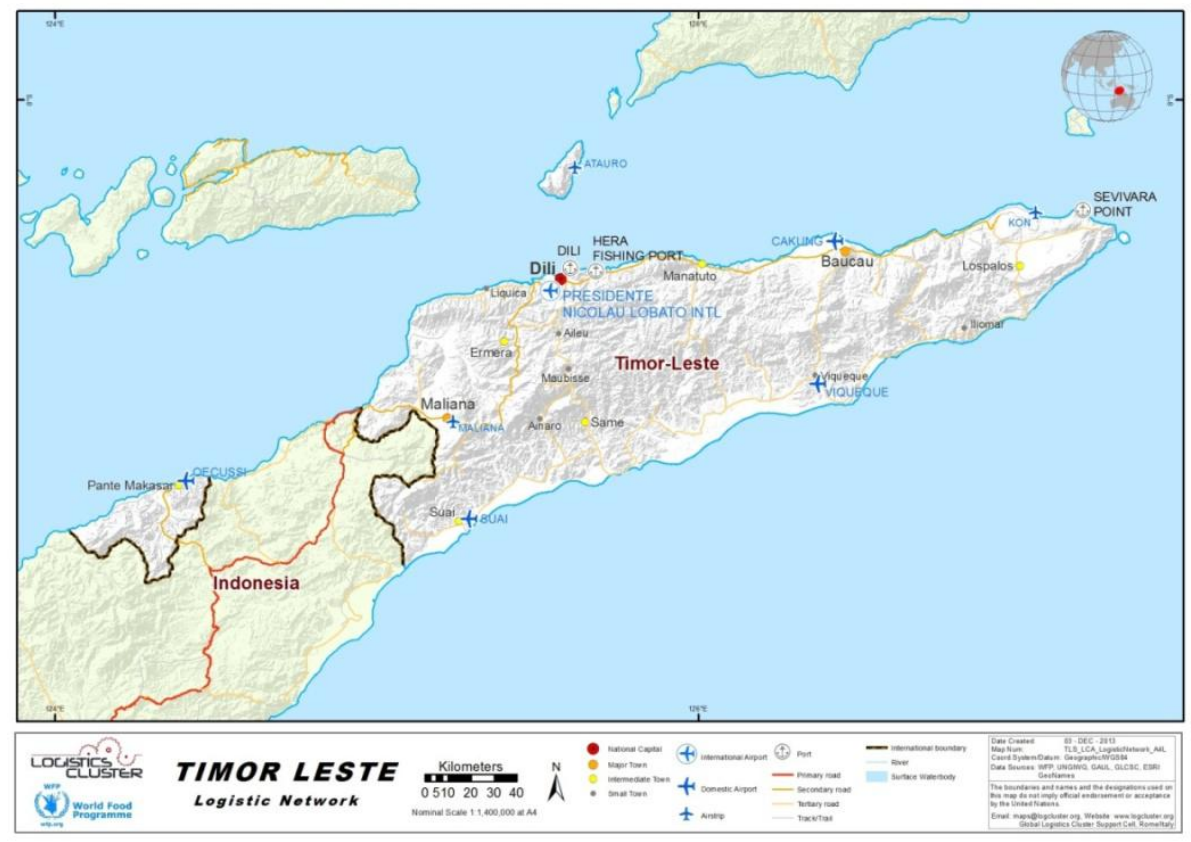

Figure 6. Timor Leste Air and Sea Transportation

\section{The Road Network System Model}

For analyzing the connectivity road system model is needed. The road network system model consists of nodes connected by links, classified by all different types of vehicle needed, in the region. The nodes consists of nodes representing the national activitiy center and the auxiliary nodes representing road junctions. The links representing the road to be analyzed, classified by class of vehicle possible to circulate on.

For this analyze, the Road Vehicle must be classified into motorcycle, tricycle, sedan, SUV as private vehicle; into micro bus, medium bus, standard bus, for public transport vehicle; and into pick-up, small truck, medium truck, large truck for freight vehicle.

The nodes for this model consists of the capital, 11 indistricts, 1 outdistricts, 2 airports and 1 seaport. The list of the nodes is presented in Table 1 below. 
Tabel 1. List of National Activities Center

\begin{tabular}{llllcc}
\hline \multirow{2}{*}{ Group } & No & Dis trict & Name & Coordinat \\
& & & & $m$ & $\mathbf{S}$ \\
\hline Capital & 1 & Capital & Dili & $783,928.07$ & $9,053,583.81$ \\
\hline \multirow{6}{*}{ District } & 2 & Bobonaro & Maliana & $744,066.54$ & $9,005,277.61$ \\
& 3 & Cova Lima & Suai & $748,539.86$ & $8,969,083.18$ \\
& 4 & Liquica & Liquica & $858,876.14$ & $9,050,190.69$ \\
& 5 & Ermera & Gleno & $768,028.19$ & $9,034,839.27$ \\
& 6 & Ainaro & Ainaro & $775,472.59$ & $9,004,568.50$ \\
& 7 & Aileu & Aileu & $782,337.60$ & $9,034,549.35$ \\
& 9 & Manufahi & Same & $791,270.80$ & $9,004,235.94$ \\
& 10 & Baucau & Manatuto & $170,493.47$ & $9,057,098.52$ \\
& 11 & Viqueque & Baucau & $219,540.83$ & $9,063,559.95$ \\
& 12 & Lautem & Viqueque & $210,023.77$ & $9,020,102.68$ \\
& 13 & Oecussi-Ambeno & Pante Macassar & $279,417.74$ & $9,057,342.94$ \\
\hline \multirow{2}{*}{ Airport } & 14 & Int. Airport & Presidente Nicolao Lobato & $770,667.89$ & $8,982,602.03$ \\
\hline \multirow{2}{*}{ Seaport } & 15 & Dom. Airport & Rota do Sandalo & $646,941.77$ & $8,982,504.22$ \\
\hline
\end{tabular}

The connecting links among the node, for this analyse, are the whole segments of National Road Network. The road pavement can be said in good condition for the whole segments, after an extensive road development. But, due to the rough mountainous and hilly terrain, at a lot of points the road geometric is rough, turtously climb the hilly terrain.

For the purposes to assess the Connectivity Quality, the Road Network System Model can be developed as node connected by the straight links. The nodes represent the 16 National Center Activities above. The straight line links represent the national road segments connecting the nodes. The Road Network System is presented the Figure 1 below.

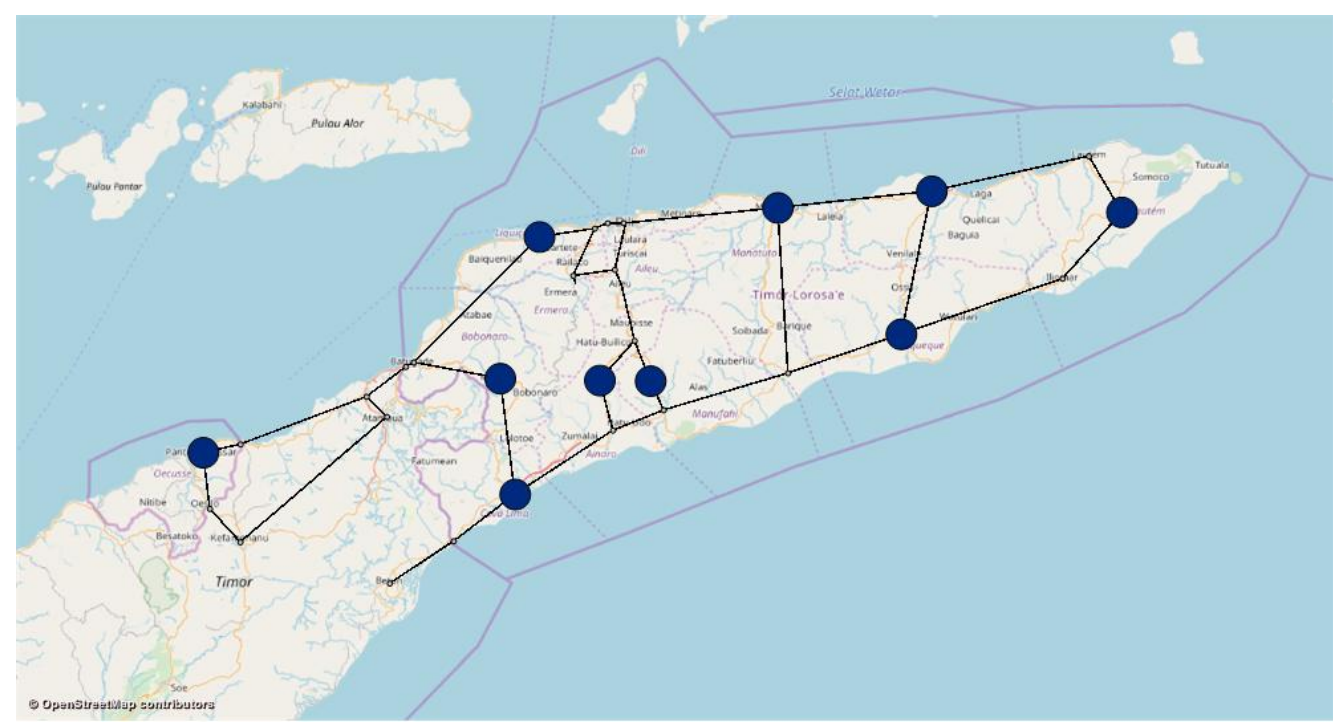

Figure 7. Road Network System Connectivity Model

\section{Connectivity Assessment}

All nodes are connected by national roads. Due to the existence of mountainous area the adjacent nodes are not always directed conneceted. Even if all the nodes are connected, but 
the connection are not all good enough due to the geometric conditions of the road segments in certain points.

The road network development should prioritized the connecting road segments from each district to the capital, where we can find the offices of center administration, the higher education facilities, the main hospital, the international airport, the seaport. The development should consists of road cross section widenth, geometric condition, the road marks and signs.

\section{CONCLUSIONS}

This research on the connectivity of Timor Leste road network has been well finished. Principal conclusions can be written as follows.

- Timor Leste domestic transport is practically all done by road transport.

- International conection is served by road, air and sea transport.

- Presidente Nicolao Lobato airport and Porto Dili seaport are the international main connections for passenger and freight.

- Vehicle types in circulation for road transport are motorcycle, tricycle, sedan, SUV, micro bus, medium bus and standrad bus, pickup, light truck, medium truck and 2 axles heavy truck.

- The national activity center consists of the capital Dili City, the two main airports, the main sea port, and all district capitals.

- The national road network is already well connected all national activity center for all type of vehicles in circulation.

- Certain road segment need to be improved in term of road width, road drainage, road geometric design and road traffic facilities.

This research induces certain curiousity on further research, i.e. connectivity quality parameter calculation, transportation supply-demand modelling, traffic condition analysis, transport related economic condition of Timor Leste, international passenger and freight trip distribution in Timor Leste, road network management in Timor Leste.

Notes. This paper is written as a cooperation a programme to develop the Knowledge and Science of Infrastructure and Facility Asset Management.

\section{REFERENCES}

ADB (2018). Timor-Leste Transport Operations. Country Infrastructure Study, November 2018. Asian Development Bank.

GHD (2015). Draft - Timor Leste Transport Sector Master Plan. GHD Engineering Company. Melbourne.

Suprayitno, Hitapriya (2010). "Road Network Quality Components, Case of Rural Road Network with Low Traffics". APTE Seminar 2010. Semarang.

Suprayitno, Hitapriya (2014). Metoda Penilaian Kualitas Jaringan Jalan Utama di Wilayah

Kabupaten. Disertasi RC 09-3399. Jurusan Teknik Sipil. Institut Teknologi Sepuluh Nopember (ITS). Surabaya.

Suprayitno, Hitapriya (2015). "Traffic Flow Quality as Part of Network Quality for a Sparse Road Network". Proceedia Engineering 125 (2015) 564-570.

Suprayitno, Hitapriya (2016). "In Search of Basic Principles for Transportation Network Analysis". Seminar Nasional FSTPT, Banda Aceh, 2016.

Suprayitno, Hitapriya (2018). "The Connectivity Quality as Part of Network Quality for a Sparse Road Network". Jurnal Transportasi : Sistem, Material dan Infrastruktur, Vol. 1, No. 1, pp. 23-34. 


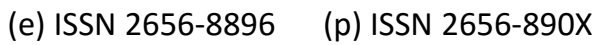
Journal of Infrastructure and Facility Asset Management - Vol. 1. Issue. 2, September 2019

Suprayitno, H. \& Soemitro, R.A.A. (2018). "Preliminary Reflexion on Basic Principle of Infrastructure Asset Management". Jurnal Manajemen Aset Infrastruktur \& Fasilitas, Vol. 2, No. 1, Maret 2018, Hal. : 1-9.

Suprayitno \& Soemitro (2019). "Reflection on Basic View of Public Infrastructure for Infrastructure Asset Management in Indonesia". Jurnal Manajemen Aset Infrastruktur dan Fasilitas, Vol. 3, Suplemen 1. Juni 2019.

WBG (2018). Timor Leste - Economic Report - March 2018. World Bank Group. Washington. 